\title{
Assess the Effects of Leakage Current on Reinforced Concrete in a Connected Building System
}

\author{
Rohollah Abdollahi ${ }^{1}$ \\ Technical and Vocational University, Qom, Iran \\ Submission: October 10, 2019; Published: August 13, 2020 \\ *Corresponding author: Rohollah Abdollahi, Technical and Vocational University, Qom, Iran
}

\begin{abstract}
Armed concrete has been used as an effective and safe German for over 50 years in industrial, commercial systems, as well as systems protection systems. Concrete acts as a suitable substrate such as many moist soils, such as an active media environment. The ability of the concrete to accelerate moisture absorption and stability, in the long run, makes the task of implementing the earth electrode, especially for dry places. Over the years, the use of the buried electrodes in the concrete has reached full maturity. The primary concerns for dealing with large currents and preventing local rapid warming and blowing up concrete supports of embedded metal conductors have been considered. However, new concerns appeared and should be addressed by industry experts. A new concern is the long - term impact of small currents on rebar corrosion and the creation of micro-cracks around concrete connections. In this paper, the long - term impact of small currents on armed concrete has been tested and tested. Experimental results show that long - term passage of building leakage currents in the connected building system causes compressive strength reduction, reduction of concrete durability and increased penetration of reinforced concrete. The flow passage through the reinforced concrete leads to an increase in the temperature of the concrete and thus the evaporation of the water present in it, and the water vapor pressure causes the penetration of the voids of concrete to the boundary of the sand and sand. In addition, the evaporation of the concrete also leads to an increase in the electrical resistance of the reinforced concrete.
\end{abstract}

Keywords: Reinforced concrete; The electric configuration of the building; Leakage current

\section{Introduction}

During World War II, the U.S. military needed an electrical ground system to protect bomb storage depots in the desert regions of Arizona. Conventional land systems did not work well in this place because it is a desert, lacking any aquifers, and annual rainfall. In very dry soil conditions, hundreds of meters of copper rods were placed before the lightning to protect the buildings to protect the buildings. In 1942, Mr. Ufer, as a U.S. military adviser, sought to find a less expensive and practical solution to the land system to replace the traditional copper bars at this dry place. The discovery of Mr. Ufer was that the conductivity of the concrete was much better than most of the soil types. The basis of his design is based on the embedding of the ground in the concrete. Experience and tests show that this method is very effective. After the war, Mr. Ufer developed his method and presented the results in an article in 1964 [1]. The engineers are now aware of the interest of the discovery of Mr. Ufer, the whole reinforced concrete building with a very low resistivity of the steel bars on either side or by the cover concrete.
The land system is very simple, effective, inexpensive, and applicable to new buildings. The advantage of the Earth system is to use the concrete properties to reduce the ground resistance. Concrete quickly absorbs moisture if it is very calm to lose moisture. The properties of the concrete materials (lime and other materials) are primarily alkaline and highly PH. Therefore, the concrete with alkali property acts as a source of the ion supply for conduction of electric current. The penetration of leachate to the soil around the concrete leads to an increase in the $\mathrm{pH}$ of the soil in the area and consequently the total soil impedance is reduced. Increasing the volume and surface area of the soil adjacent to the soil helps in reducing the connection resistance and provides a good conductor for passage of the land flow or the flow induced by the soil. The Ufer technique in the wake of concrete structures, concrete buildings, telecommunication towers, power transmission towers, and electric poles were used, the original design of the original Uofer was the use of copper in concrete. However, the high $\mathrm{pH}$ of the concrete often causes a sheet 
of copper. For this reason, steel is often used instead of copper. The minimum length of the rebar needed to avoid damage to concrete is dependent on factors such as the type of concrete, compounds, density, electrical resistivity, PH, surface area of concrete with soil, soil resistivity and surface soil compounds, wires, or planes inside the concrete. The use of reinforced concrete plots in concrete in 1968 was added to the United States National Electrical Standard (NEC) [2]. In 1978, NEC identified the requirements of the rebar as a ground electrode and named Ground as a "Concrete Encased Electrode" (CEE) instead of Ufer Ground.

\section{Evaluation of the Effects of Leakage Current on Armed Concrete}

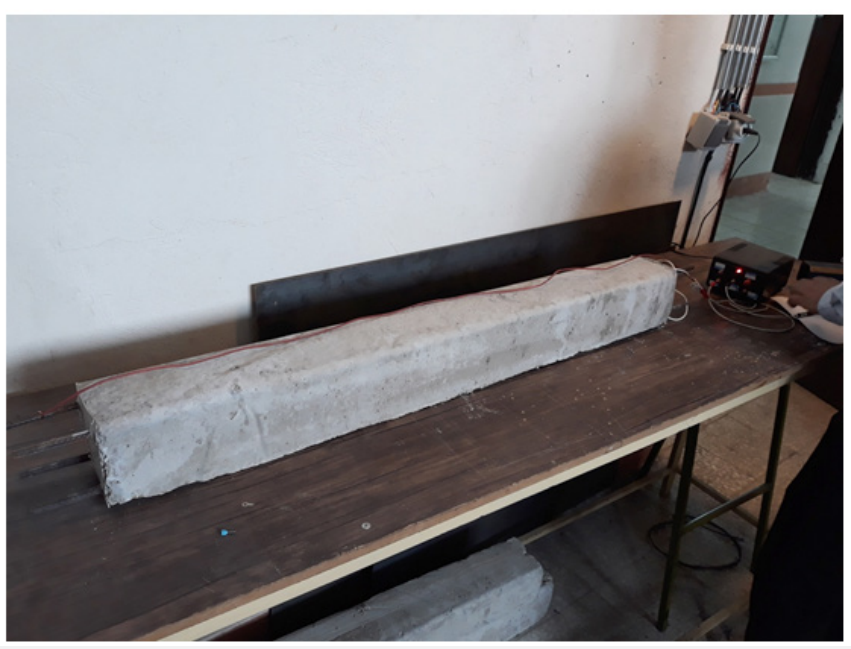

Figure 1: The experimental specimen of the armed concrete under the flow of the leakage current.

In order to investigate the impact of the leakage current from the armed concrete of buildings in the connected system, two specimens were fabricated using the same dimensions, materials, and experimental conditions (Figure 1). An example is affected by the flow of leakage current over a period of 3 months and another example without the leakage current through the test. The purpose of the concrete test is to evaluate the effects of the passing of the leakage current in the Armed Concrete tract. In addition, the Schmidt hammer destructive test method has been used in five points of the concrete piece.
The results of the compressive strength test of the concrete by Schmidt hammer are presented in Table 1 . The results show that the compressive strength of the specimen under the leakage current has decreased by around $2 \%$. The flow passage through the reinforced concrete leads to an increase in the temperature of the concrete and thus the evaporation of the water present in it, and the water vapor pressure causes the penetration of the voids of concrete to the boundary of the sand and sand. In addition, the evaporation of the concrete also leads to an increase in the electrical resistance of the reinforced concrete.

Table 1: Results of the compressive strength test by Schmidt hammer.

\begin{tabular}{|c|c|c|}
\hline Test point & Sample resistance without leakage of leakage current $\left.\mathbf{( k g} / \mathbf{~ m}^{2}\right)$ & Sample resistance by passage of leakage current $\left(\mathbf{k g} / \mathbf{c m}^{2}\right)$ \\
\hline 1 & 311 & 305 \\
\hline 2 & 290 & 286 \\
\hline 3 & 301 & 295 \\
\hline 4 & 315 & 309 \\
\hline 5 & 320 & 314 \\
\hline
\end{tabular}

\section{Conclusion}

In this paper, the long - term impact of small currents on armed concrete has been tested and tested. Experimental results show that long - term passage of building leakage currents in the connected building system causes compressive strength reduction, reduction of concrete durability and increased penetration of reinforced concrete. The flow passage through the reinforced concrete leads to an increase in the temperature of the concrete and thus the evaporation of the water present in it, and the water vapor pressure causes the penetration of the voids of concrete to the boundary of the sand and sand. In addition, the evaporation of the concrete also leads to an increase in the electrical resistance of the reinforced concrete. 


\section{Civil Engineering Research Journal}

\section{References}

1. Ufer HG (1964) Investigation and Testing of Footing-Type Grounding Electrodes for Electrical Installations, IEEE Transactions on Power Apparatus and Systems 83(10): 1042-1048.

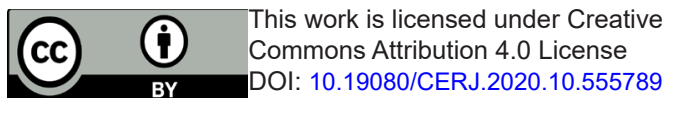

2. (1968) National Electrical Code a USA Standard.

\section{Your next submission with Juniper Publishers will reach you the below assets}

- Quality Editorial service

- Swift Peer Review

- Reprints availability

- E-prints Service

- Manuscript Podcast for convenient understanding

- Global attainment for your research

- Manuscript accessibility in different formats

( Pdf, E-pub, Full Text, Audio)

- Unceasing customer service

Track the below URL for one-step submission https://juniperpublishers.com/online-submission.php 